\title{
BMJ Open Aussiedler Mortality (AMOR): cohort studies on ethnic German migrants from the Former Soviet Union
}

\author{
Volker Winkler, ${ }^{1}$ Simone Kaucher, ${ }^{1}$ Andreas Deckert, ${ }^{1}$ Valentina Leier, ${ }^{2}$ \\ Bernd Holleczek, ${ }^{3}$ Christa Meisinger, ${ }^{4,5}$ Oliver Razum, ${ }^{6}$ Heiko Becher ${ }^{1,2}$
}

To cite: Winkler V, Kaucher S, Deckert A, et al. Aussiedler Mortality (AMOR): cohort studies on ethnic German migrants from the Former Soviet Union. BMJ Open 2019;9:e024865. doi:10.1136/ bmjopen-2018-024865

- Prepublication history for this paper is available online. To view these files, please visit the journal online (http://dx.doi. org/10.1136/bmjopen-2018024865).

Received 21 June 2018 Revised 11 December 2018 Accepted 17 December 2018

Check for updates

(C) Author(s) (or their employer(s)) 2019. Re-use permitted under CC BY-NC. No commercial re-use. See rights and permissions. Published by BMJ.

${ }^{1}$ Institute of Global Health, University Hospital Heidelberg, Heidelberg, Germany

${ }^{2}$ Medical Biometry and

Epidemiology, University Medical Center Hamburg-Eppendorf, Hamburg, Germany

${ }^{3}$ Saarland Cancer Registry,

Saarbrücken, Germany

${ }^{4}$ UNIKA-T, Ludwig-Maximilians-

University Munich, Augsburg,

Germany

${ }^{5}$ IndependentResearch

Group Clinical Epidemiology,

GermanResearch Center

for Environmental Health,

Neuherberg, Germany

${ }^{6}$ Epidemiology and International

Public Health, Bielefeld

University, Bielefeld, Germany

Correspondence to

Dr Heiko Becher;

h.becher@uke.de

\section{ABSTRACT}

Purpose The Aussiedler Mortality cohorts represent the unique migrant group of ethnic Germans (resettlers) from the former Soviet Union who migrated to Germany mainly after the fall of the iron curtain in 1989. Resettlers are the second largest migrant group in Germany and their health status was largely unknown before the cohorts were set up.

Participants Four retrospective register-based cohorts were set up in different federal states of Germany, each focussing on different health aspects. In total, the cohorts include 92362 resettlers (men: $51.5 \%$, women 48.5\%) who immigrated between 1990 and 2005 with a mean age at immigration of 36.6 years (range 0-105 years). Resettlers are of German ancestry and they are immediately granted the German citizenship with all rights and duties.

Findings to date Vital status and causes of death (International Classification of Diseases codes based on death certificates or record linkage) were collected for three cohorts as well as cancer incidence and incidence of acute myocardial infarction in three of the cohorts. Currently, an observation period of 20 years (1990-2009) is covered. Overall mortality among resettlers was surprisingly lower in comparison to the German population with standardised mortality ratios of 0.87 (95\% confidence limits 0.84-0.91) for women and $0.96(0.92-0.99)$ for men, and even stronger for cardiovascular diseases (women: 0.84 (0.79-0.89); men: 0.80 (0.75-0.86). However, observed differences can neither be explained by the 'healthy migrant effect' nor by common behavioural risk factors and may be related to factors which have not yet been studied.

Future plans The existing cohorts will be continued and prospective studies on resettlers are underway: one cohort will be followed-up prospectively and two other large prospective cohort studies in Germany will be used for a detailed assessment of lifestyle, environmental and genetic/epigenetic factors on the mortality and morbidity pattern of resettlers.

\section{INTRODUCTION}

Studies on migrant populations contribute to knowledge on aetiology of diseases and reveal differences in the health status of migrants compared with the autochthonous population. The differences in the health

\section{Strengths and limitations of this study}

- The four retrospective cohorts represent the unique migrant group of ethnic Germans (resettlers) from the Former Soviet Union.

- They include 92362 resettlers (men: $51.5 \%$, women: $48.5 \%$ ) who immigrated to Germany between 1990 and 2005.

- The register-based cohorts cover an observation period of 20 years (1990-2009) and observed vital status and causes of death, as well as cancer incidence and incidence of acute myocardial infarction.

- Since the cohorts are using secondary data, there is no individual information on risk factors or sociodemographic information.

- The nested case-control and cross-sectional studies are limited due to relatively low response.

status are often linked to different exposure profiles in migrants' respective country of origin, to the migration process itself and to the integration process in the host country. ${ }^{1-4}$ Furthermore, language barriers and cultural differences play an important role regarding healthcare utilisation, which often differs among migrants compared with the host populations. ${ }^{5}$ Prominent examples of migrant cohorts are studies on Asian migrants in the USA. $^{6-8}$

Migration is a worldwide phenomenon, driven by economic, social and political reasons, along with enormous implications on individuals and societies. Although Germany has not typically been considered as a country of immigration, it has been welcoming migrants for decades. People with Turkish background and people with ethnic German background of Eastern European countries constitute by far the two largest migrant groups in Germany. ${ }^{9}$ Whereas Turkish migrants can partly be attributed to labour migration in the early 1960s, ethnic German migrants are a unique group of descendants of ethnic Germans. Since 1953, ethnic Germans and their families, including 


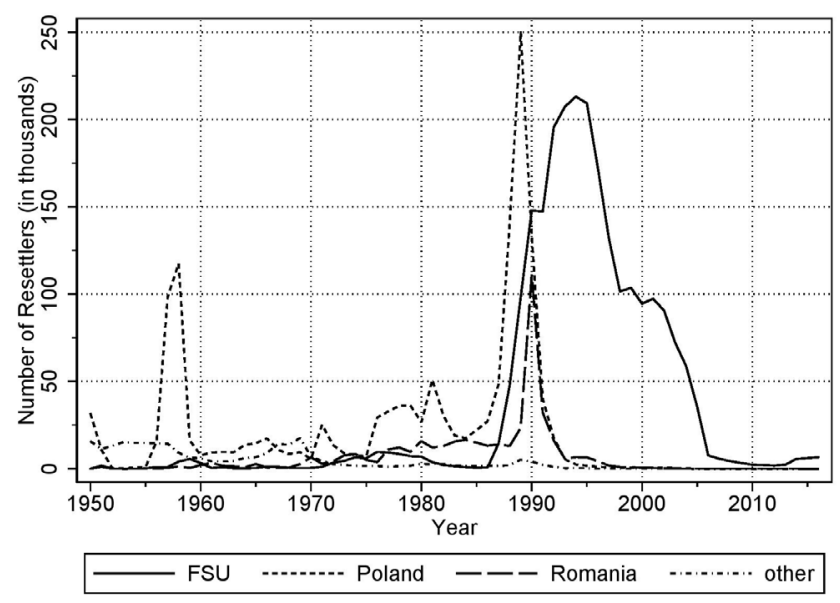

Figure 1 Immigration of resettlers between 1950 and 2016 by country of origin. ${ }^{12}$ FSU, Former Soviet Union.

non-German spouses and their descendants, are allowed to move to Germany based on the Federal Expellee Law. These ethnic German migrants are legally called Aussiedler ('resettlers') or, since 1993, Spätaussiedler (literally 'late resettlers'). To simplify matters, we will use the term 'resettlers' for both groups. By law, on arrival, resettlers are immediately granted the German citizenship with all rights and duties. ${ }^{10}$ In 2015 , about $4 \%$ of the German population consisted of resettlers who had migrated themselves, coming from different Eastern European countries such as Romania, Poland and the Former Soviet Union (FSU). ${ }^{10}$ Country-specific immigration patterns are closely linked to the political situation in the country of origin and are displayed in figure 1.

Only few, moved before the breakdown of the Soviet Union and opening of the inner German border in 1989, and most of them came from Poland. Since the fall of the Iron Curtain, resettlers' origin shifted almost exclusively to FSU countries. Originally, the ancestors of the FSU resettlers emigrated to the Russian empire in the 18th and 19th century, by invitation of the government. They were privileged compared with the Russian population, but at beginning of the 20th century, they became victims of persecution and suffered increasing discrimination. Many ethnic Germans were deported to Kazakhstan and Siberia in 1941 when Nazi Germany launched the invasion of the Soviet Union and forced to work in agriculture. After the World War II, their population recovered in new settlement areas and many continued to preserve their distinct cultural identity. However, they were not allowed to return to their original places of residence. ${ }^{11}$

The Aussiedler Mortality (AMOR) cohorts constitute of resettlers from the FSU who immigrated since the collapse of the Soviet Union in 1990. Altogether, between 1990 and 2016, about 2.53 million resettlers, including spouses and descendants, immigrated to Germany, thereof 2.12 million resettlers from countries of the FSU. ${ }^{12}$ As shown in figure 1 , there was a large influx of resettlers between 1990 and 1994, which was more and

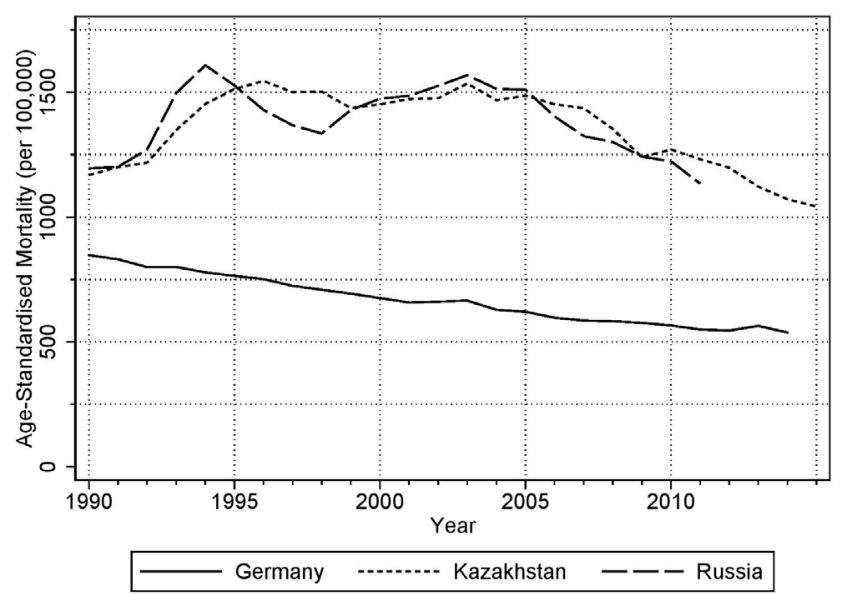

Figure 2 Age-standardised all-cause mortality (European standard) of Russia, Kazakhstan and Germany since $1990 .^{38}$

more regulated in 1993 and 1996 by restricting the maximum number of immigrants accepted per year, and by a new legal requirement to prove German language skills already before departure, respectively. ${ }^{13} 14$ Since 2005 , the yearly number of arriving resettlers considerably decreased and remains low since. There are conflicting data on the total number of ethnic Germans living in the FSU before 1990. However, it is assumed that most of them have migrated to Germany which also explains the decrease in yearly numbers after $2005 .{ }^{15}$ To avoid (self-) segregation, the German government assigned resettlers to a place of residence for at least 2 years based on a quasirandom procedure, considering population density and economic performance of the municipalities/counties. ${ }^{14}$

Figure 2 displays age-standardised all-cause mortality rates of the FSU countries Russia and Kazakhstan and of Germany since 1990. Russia and Kazakhstan constitute the countries of origin of most of the resettlers from the FSU. Mortality in these countries was considerably higher compared with Germany. In Germany, mortality rates decreased steadily, but in Russia and Kazakhstan, rates increased until 2003. In addition to higher all-cause mortality, differences in cardiovascular and external cause mortality were even more pronounced. There were also cancer-specific differences in incidence and mortality. For example, gastric cancer was and still is much more common in these Eastern European countries, whereas breast and prostate cancer incidence and mortality are lower than in Germany. Many of the differences can be explained by specific patterns of risk factors such as tobacco smoking and alcohol consumption, as well as poor diet and deteriorating public healthcare. ${ }^{16-18}$

In 2004, the first cohort of resettlers from the FSU was set up in the federal state of North Rhine-Westphalia (NRW) to assess mortality patterns. Given the high mortality rates in FSU countries, the initial hypothesis was that resettlers import similar health profiles as observed in FSU countries, which would have demanded public health actions. Living conditions as well as lifestyle and 
behaviour among resettlers were assumed to be similar to those of the autochthonous populations in Russia and Kazakhstan. Further, resettlers were exposed to the same climatic conditions and had the same access to goods of daily life in the respective country. Based on that, the following hypotheses for a mortality comparison between resettlers and the German population were formulated:

- higher all-cause mortality among resettlers

- higher mortality due to cardiovascular diseases among resettlers

- cancer site-specific mortality differences between resettlers and the German population

- higher mortality due to external causes of death among resettlers.

In 2009 and 2014, the second and third cohort was initiated to specifically address cancer and cardiovascular diseases (CVD) incidence and mortality among resettlers. The second cohort was set up in the federal state of the Saarland and in close cooperation with the federal population-based cancer registry. The third cohort was based in the region of Augsburg in the federal state of Bavaria in cooperation with the local population-based myocardial infarction registry (MIR), which is part of the Cooperative Health Research in the Region of Augsburg (KORA) study platform. A fourth cohort has recently been added in the administrative district of Münster, a part of NRW which also provides cancer incidence data since the early 1990s through a first, local, and, later, federal cancer registry. It is important to emphasise that the resettlers' German citizenship prevents their direct identification in German registry data such as civil registers or cause of death statistics. The setting-up of the first three AMOR cohorts was funded by the German Research Foundation (DFG), the fourth cohort is funded by the German Cancer Aid.

\section{COHORT DESCRIPTION}

All AMOR cohorts consist of representative or full samples of resettlers from the FSU who immigrated after 1 January 1990 to the respective study areas. Characteristics of the cohorts are shown in table 1 . Sex distribution, year of immigration and age at immigration pattern of the cohorts follow pattern seen in Germany-wide data on all immigrating FSU resettlers. ${ }^{19} 20$

The NRW cohort is a sample of 34393 individuals from all 281356 resettlers who were assigned to the federal state of NRW between 1990 and 2001. Information on

Table 1 Characteristics of the Aussiedler Mortality cohorts including descriptive statistics

\begin{tabular}{|c|c|c|c|c|c|}
\hline Inclusion criteria & $\begin{array}{l}\text { North Rhine- } \\
\text { Westphalia (NRW) }\end{array}$ & Saarland & Augsburg & Münster & Total \\
\hline $\begin{array}{l}\text { First residence } \\
\text { (study area) }\end{array}$ & Federal state NRW & $\begin{array}{l}\text { Federal state } \\
\text { Saarland }\end{array}$ & $\begin{array}{l}\text { Region of Augsburg } \\
\text { (Bavaria) }\end{array}$ & $\begin{array}{l}\text { Administrative } \\
\text { district Münster } \\
\text { (NRW) }\end{array}$ & \\
\hline Age at immigration & $>15$ years & No restriction & No restriction & No restriction & \\
\hline Immigration period & 1990-2001 & 1990-2005 & 1990-1999 & 1990-2001 & 1990-2005 \\
\hline $\begin{array}{l}\text { Cooperating } \\
\text { partners }\end{array}$ & - & $\begin{array}{l}\text { Saarland Cancer } \\
\text { Registry }\end{array}$ & KORA study platform & $\begin{array}{l}\text { NRW Cancer } \\
\text { Registry }\end{array}$ & \\
\hline Women & $17659(51.3 \%)$ & $9640(51.8 \%)$ & $3347(52.5 \%)$ & $16939(51.4 \%)$ & $47585(51.5 \%)$ \\
\hline \multicolumn{6}{|l|}{ Year of immigration } \\
\hline 1990-1992 & 10537 (30.6\%) & $5168(27.8 \%)$ & $1662(26.1 \%)$ & $9363(28.4 \%)$ & $26730(28.9 \%)$ \\
\hline 1993-1995 & $11211(32.6 \%)$ & $5227(28.1 \%)$ & $2199(34.5 \%)$ & $9863(29.9 \%)$ & $28500(30.9 \%)$ \\
\hline $1996-1998$ & $6433(18.7 \%)$ & $3930(21.1 \%)$ & $1793(28.1 \%)$ & $8344(25.3 \%)$ & $20500(22.2 \%)$ \\
\hline 1999+ & $6212(18.1 \%)$ & $4294(23.1 \%)$ & $724(11.4 \%)$ & $5402(16.4 \%)$ & $16632(18.0 \%)$ \\
\hline \multicolumn{6}{|l|}{ Age at immigration } \\
\hline$<18$ & $2151(6.3 \%)$ & $5207(28.0 \%)$ & $2178(34.1 \%)$ & $11598(35.2 \%)$ & $21134(22.9 \%)$ \\
\hline $18-34$ & 12668 (36.8\%) & $5325(28.6 \%)$ & $1611(25.3 \%)$ & $9217(28.0 \%)$ & $28821(31.2 \%)$ \\
\hline
\end{tabular}


all resettlers were available from the central reception centre of NRW. Sampled resettlers were at least 15 years of age at immigration and their first residence had been assigned to municipalities/counties with electronic population registries. The 34393 resettlers represent $91 \%$ of all resettlers of the respective municipalities/counties. Since assignment to the different municipalities within a state was done on a random basis, the selected cohort constitutes a random sample of all resettlers. ${ }^{21}$

The Saarland cohort was established in cooperation with the Saarland cancer registry and aimed to incorporate FSU resettlers who immigrated between 1990 and 2005 and were assigned to the federal state of the Saarland. ${ }^{22}$ Resettlers were identified by collecting application forms on obtaining German passports in all local refugee offices of the Saarland. The cohort included all resettlers whose date of birth was available resulting in a sample of
18619 individuals $(64.2 \%$ of all resettlers). This cohort was focused on cancer incidence.

The cohort established in the region of Augsburg within the federal state of Bavaria consists of all FSU resettlers who have been allocated to local transition hostels in Augsburg between 1990 and 1999 where all resettlers have first been assigned to. This study was conducted in cooperation with the KORA study platform and the MIR of Augsburg. ${ }^{23}$ Additional to capturing mortality data, the incidence of acute myocardial infarction (fatal and non-fatal cases) (AMI) was assessed for those living in the catchment area of the MIR. Further, in a subsample of resettlers, a cross-sectional survey was performed, followed by a detailed physical and medical examination of their health status as well as their lifestyle.

The Münster cohort, where the follow-up is still ongoing, is a sample of 32972 resettlers (53\% of all resettlers) that

Table 2 Descriptive follow-up results of the AMOR cohorts (excluding Munster)

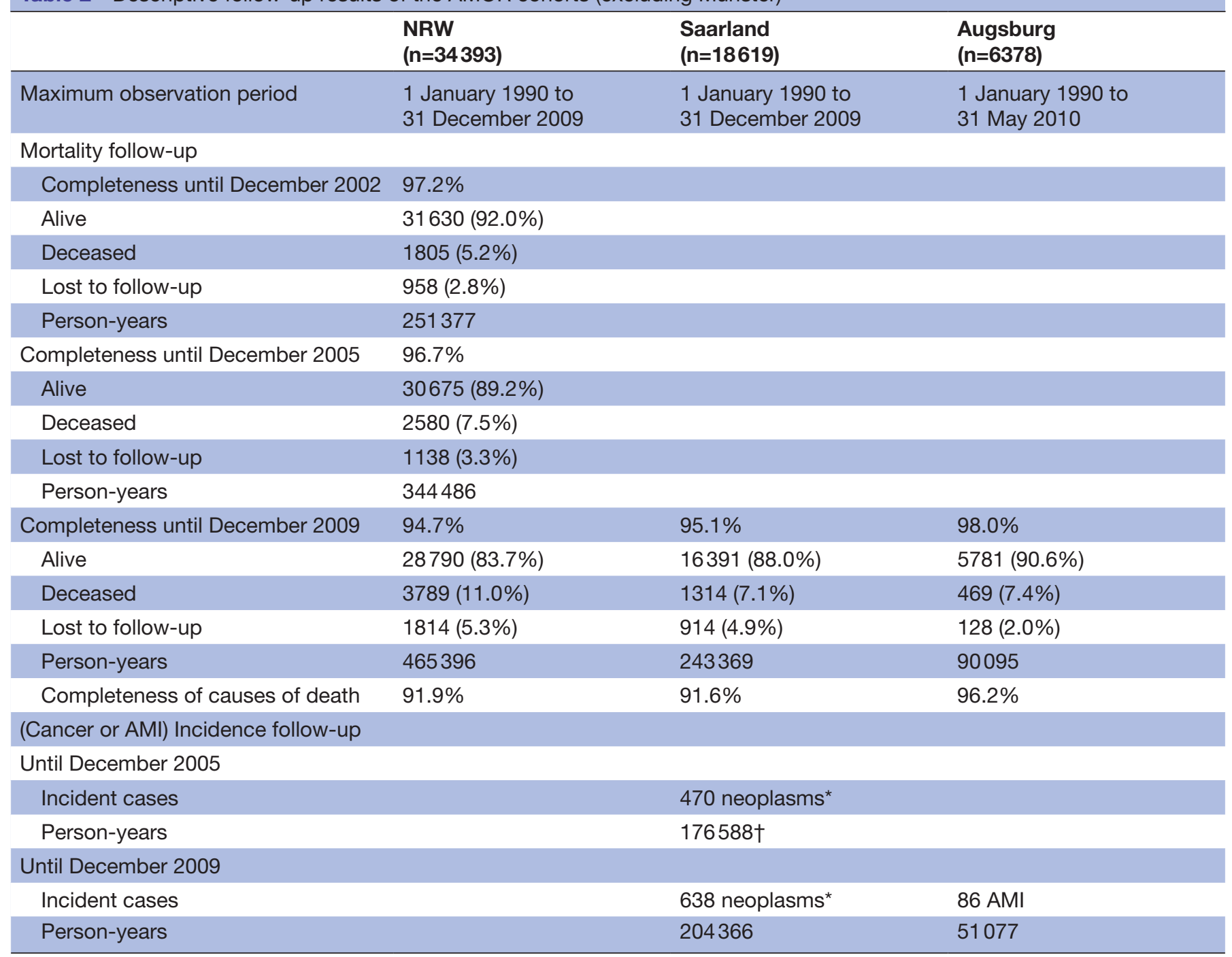

*All malignant neoplasms except non-melanoma skin cancer (International Classification of Diseases-10: C44). †Estimated based on. ${ }^{39}$

AMI, acute myocardial infarction; AMOR, Aussiedler Mortality; NRW, North Rhine-Westphalia. 
could be identified in local registry offices who approved the identification procedure (50\% of all local registries). The immigration period was between 1990 and 2001. In this study, cancer incidence data are collected in cooperation with the federal cancer registry of NRW.

All cohorts reflect expected distributions of sex, year and age of immigration when compared with national statistics of immigrated resettlers which indicates that the cohorts are representative for this migrant group.

Table 2 provides an overview of the descriptive follow-up results for each of the retrospective, register-based cohorts excluding the Münster cohort (follow-up ongoing). Vital status of the NRW cohort was already followed up to three different time points, whereas the Saarland and the Augsburg cohort were followed up once. ${ }^{22-26}$ Until today, all established cohorts cover an observation period for the mortality follow-up of 20 years. Cancer incidence of the Saarland cohort was followed-up twice and AMI incidence in the region of Augsburg once. ${ }^{25} 27$

The three AMOR cohorts NRW, Saarland and Augsburg used the same register-based procedure to assess the vital status of the cohort members as well as the cause of death of all deceased members. Vital status was ascertained Germany-wide through local population registries by record linkage or manually. Individuals who changed residence were followed-up subsequently through local population registries and censored when moving out of Germany or at their last known date of moving, deceased participants at the date of death. For deceased cohort members, date and place of death was collected, and after deleting individuals' identifying information, the cause of death was provided by local health authorities in an anonymised death certificate or electronically by using record linkage. All causes of death were coded according to the International Classification of Diseases, edition 9 (until 1997) or edition 10 (since 1998).

Cancer incidence data of the Saarland cohort were provided by the Saarland Cancer Registry through record linkage using phonetic code of first and last name, sex, date of birth and city of residence. In the Münster cohort, a different record linkage procedure was applied. In addition to the standard record linkage system using a stochastic method, a thesaurus of common changes of the first and last name when transcribing them from Kyrillic to German alphabet was used to identify all incident cancer cases among cohort members. Thereby, probability-based weights were assigned to pairs of records. ${ }^{28}$ The thesaurus was built on the information collected from the other three cohorts and was intended to increase the success rate of the record linkage.

The MIR provides data on incidence of AMIs for individuals in the region of Augsburg between ages 25 and $74 .{ }^{29}$ Cohort members affected by AMIs were identified by record linkage based on sex, initials of the names and date of birth. For the incidence follow-up, cohort members were censored when they moved out of the MIR catchment area and at age 75 .

In addition to the above described record linkages to routine data sources for morbidity and mortality, further studies have been nested into the AMOR cohorts. A list of these studies, also containing the phase when the respective study was nested, is provided in table 3 . A nested case-control study ( $\mathrm{n}=348,38 \%$ response) was performed within the NRW cohort after the follow-up until 2005. ${ }^{30}$ Relatives of cohort members who died from CVD and controls themselves were interviewed by telephone using a standardised questionnaire. The aim was to identify and to quantify CVD risk factors. A nested cross-sectional study ( $\mathrm{n}=114,16 \%$ response) was conducted within a random sample of the Saarland cohort after the incidence follow-up of 2005 and during the mortality follow-up. The aim was to assess drug consumption, handling and administering drugs in the light of reported health status and socio-demographic characteristics. ${ }^{31}$ Another nested cross-sectional study was conducted within the Augsburg cohort in 2012. First, a questionnaire-based survey was applied to all resettlers alive in 2010 and still living in Augsburg region ( $\mathrm{n}=3742$, $16 \%$ response). Second, the respondents of the questionnaire were invited to a detailed physical and medical examination and to provide a blood sample $(n=189,32 \%$ response).

Table 3 List of studies nested into the different Aussiedler Mortality cohorts

\begin{tabular}{|c|c|c|c|}
\hline & North Rhine-Westphalia & Saarland & Augsburg \\
\hline After the follow-up until 2005 & $\begin{array}{l}\text { Nested case-control study } \\
\text { ( } n=348 \text { ): cardiovascular } \\
\text { disease risk factors } \\
\text { (interviews) }\end{array}$ & $\begin{array}{l}\text { nested cross-sectional } \\
\text { study }(n=114) \text { : drug } \\
\text { utilisation } \\
\text { (questionnaires) }\end{array}$ & \\
\hline $\begin{array}{l}\text { After the follow-up until } 2009 \\
\text { (Augsburg until May 2010) }\end{array}$ & & & $\begin{array}{l}\text { Cross-sectional survey }(\mathrm{n}=595) \text { : lifestyle, } \\
\text { immigration background, morbidity, } \\
\text { mental health, healthcare } \\
\text { (questionnaires); cross-sectional study } \\
\text { ( } \mathrm{n}=189 \text { ): detailed lifestyle, detailed } \\
\text { immigration background, detailed } \\
\text { medical examination, interviews, blood } \\
\text { sample }\end{array}$ \\
\hline
\end{tabular}


Table 4 Cause-specific standardised mortality ratios (SMR) with 95\% confidence limits (95\% Cl) of resettlers in comparison to the general German population

\begin{tabular}{|c|c|c|c|c|}
\hline \multirow[b]{2}{*}{ Cause of death (ICD-10 code) } & \multicolumn{2}{|l|}{ Women } & \multicolumn{2}{|l|}{ Men } \\
\hline & Observed & SMR (95\% Cl) & Observed & SMR (95\% Cl) \\
\hline All causes & 2674 & $0.87(0.84$ to 0.91$)$ & 2898 & 0.96 (0.92 to 0.99$)$ \\
\hline Ischaemic heart diseases (I20-I25) & 418 & $0.80(0.72$ to 0.88$)$ & 451 & $0.79(0.72$ to 0.87$)$ \\
\hline Cerebrovascular diseases (160-169) & 258 & $0.84(0.74$ to 0.95$)$ & 178 & 0.89 (0.77 to 1.03$)$ \\
\hline Stomach (C16) & 66 & 1.52 (1.19 to 1.93$)$ & 84 & $1.62(1.31$ to 2.01$)$ \\
\hline Colorectal (C18-C21) & 92 & $0.86(0.70$ to 1.05$)$ & 77 & $0.74(0.59$ to 0.93$)$ \\
\hline Lung (C33-C34) & 62 & 0.69 (0.54 to 0.88$)$ & 307 & $1.34(1.20$ to 1.50$)$ \\
\hline Female breast (C50) & 82 & $0.55(0.44$ to 0.68$)$ & & \\
\hline Suicide (X60-X84) & 13 & $0.44(0.26$ to 0.77$)$ & 82 & $1.00(0.80$ to 1.24$)$ \\
\hline Events of undetermined intent (Y10-Y34) & 8 & $1.10(0.47$ to 2.16$)$ & 35 & $2.45(1.71$ to 3.40$)$ \\
\hline All unknown/ill-defined (R00-R99) & 109 & $1.44(1.19$ to 1.74$)$ & 160 & $1.80(1.54$ to 2.10$)$ \\
\hline
\end{tabular}

${ }^{*}$ Except non-melanoma skin cancer (ICD-10: C44).

CVD, cardiovascular diseases; ICD, International Classification of Diseases.

\section{Patient and public involvement}

Since information on cause of death as well as incidence of cancer and of AMI was retrieved anonymously by registry data, patients were not involved. For the collection on CVD risk factors, on drug utilisation and for the cross-sectional survey, individuals of the respective samples were first contacted by mail with information on the aims of the study. Later, individuals who agreed to participate were either contacted by phone (NRW) or again by mail (Saarland) or invited to the study centre (Augsburg). By signing a consent form or by a telephone call, the participants declared willingness to participate in the nested studies presented in table 3 and assured that they were informed sufficiently on the study and the further use of the data collected. Participation could be withdrawn at any time. The public was not involved in the study.

\section{Findings to date}

Results of the AMOR cohorts show that the overall mortality among resettlers from the FSU was not only lower than in the countries of the FSU, but also lower in comparison to the German population. This was especially pronounced in CVD mortality. However, it has been shown that relevant CVD risk factors such as hyperlipidaemia, obesity, tobacco smoking (among men), low physical activity and possibly non-participation in screening programmes are more prevalent among resettlers. ${ }^{30-32}$ Given the limited knowledge which also arises from the generally low response of this group to actively take part in studies, the observed differences cannot be explained and may even be related to factors which have not yet been studied.

It is important to highlight that resettlers are a unique group of migrants and a 'healthy migrant effect', which is observed in many migrant studies, is rather unlikely. Resettlers were hardly selected; in fact, they are invited to Germany and receive German citizenship on arrival. They immediately have full access to the German healthcare system, which might also have been a motivation for sick family members to migrate. This assumption is supported by deaths observed shortly after immigration. Furthermore, resettlers mostly immigrated with their complete family.

Results on cancer incidence and mortality among resettlers confirm a very different risk profile in comparison to the German population. For example, gastric cancer is strongly elevated among resettlers and within the observation time hardly attenuates to German rates. ${ }^{22} 25$ Furthermore, it was shown that the high incidence among resettlers cannot be explained by the assumed higher prevalence of Helicobacter pylori, but is strongly associated with lifestyle and dietary factors. ${ }^{33}$

Since the allocation of the resettlers was done quasi-randomly within Germany, the cohort allowed to investigate the effect of regional deprivation on individual mortality by making use of this natural experiment. The NRW cohort was used to assess the effect of regional deprivation on individual mortality by aggregating the 54 counties of NRW in six deprivation clusters. Standardised mortality ratios (SMRs) comparing resettler mortality with the 
mortality of the autochthonous population resulted in highest SMRs for regions with the highest level of regional deprivation. ${ }^{34}$

Analysis within the cohorts of the AMOR studies were also done with respect to external causes of death such as suicide and drug abuse. Here, an elevated risk was found especially for male resettlers who migrated in teenage age and frequently changed residence within Germany. ${ }^{35}$

Table 4 presents a comparison of cause-specific mortality among resettlers and the German population for the whole observation period between 1990 and 2009 for all cohorts combined (excluding the Münster cohort) as SMRs.

\section{Strengths and limitations}

The main strengths of the AMOR studies are the large representative samples of this unique group of migrants which is hard to identify in register-based data, and the high completeness of follow-up for an observation period of 20 years. All resettlers are registered within the highquality registration system of German, which reduces the likelihood of outmigration bias. Main outcomes are based on information from health authorities and high-quality registries.

Main weaknesses arise from the fact that all cohorts are based on secondary data only. There is no individual information on risk factors or socio-demographic information other than what is available from the registries. The nested case-control and cross-sectional studies are all limited by the relatively low response of this migrant group.

Further prospective studies on resettlers are underway: (1) A sample of the Augsburg cohort will be followed-up prospectively and use the cross-sectional study as its baseline. (2) There are currently two large prospective cohort studies in Germany in the recruitment phase, the National Cohort and the Hamburg City Health study. ${ }^{36}$ These studies plan to recruit 200000 and 45000 individuals, respectively. Since in these studies the response has been found to be similar in resettlers and autochthone Germans, we expect approximately $2 \%$ of the study populations to be resettlers, that is, approximately 5000 individuals. ${ }^{37}$ This sample will allow a detailed assessment of lifestyle, environmental and genetic/epigenetic factors on their mortality and morbidity pattern.

\section{Collaboration}

Data of the AMOR studies are not open access, but we encourage other researchers to contact us and apply for data access based on collaborating projects. Please, contact Professor Dr. Heiko Becher (h.becher@uke.de) or PD Dr Volker Winkler (v.winkler@uni-heidelberg.de) to apply for possible collaborations.

Acknowledgements We acknowledge financial support by Deutsche Forschungsgemeinschaft (DFG) within the funding programme OpenAccess Publishing, by the Baden-Württemberg Ministry of Science, Research and the Arts and by Ruprecht-Karls-Universität Heidelberg as well as project funding from the DFG, the German Cancer Aid and the German Federal Ministry of Education Research, Grant number01ER1306.

Contributors VW wrote the manuscript, collected part of the data and is co-PI of the study. SK, AD and VL collected parts of the data and contributed to writing of the manuscript. BH and CM enabled part of the record linkage procedures, helped with data collection and gave critical feedback to manuscript. OR and HB initiated the study and significantly contributed to writing. $\mathrm{HB}$ is the $\mathrm{Pl}$ of the study.

Funding Funding from the German Research Foundation (DFG) and the German Cancer Aid is gratefully acknowledged.

Competing interests None declared.

Patient consent for publication Obtained.

Provenance and peer review Not commissioned; externally peer reviewed.

Data sharing statement We welcome collaboration and the data will be shared with investigators. External researchers can get access to the AMOR data through collaborating projects. Please contact the principal investigators and coordinators of the study Prof. Dr. Heiko Becher (h.becher@uke.de) or PD Dr. Volker Winkler (v. winkler@uni-heidelberg.de).

Open access This is an open access article distributed in accordance with the Creative Commons Attribution Non Commercial (CC BY-NC 4.0) license, which permits others to distribute, remix, adapt, build upon this work non-commercially, and license their derivative works on different terms, provided the original work is properly cited, appropriate credit is given, any changes made indicated, and the use is non-commercial. See: http://creativecommons.org/licenses/by-nc/4.0/.

\section{REFERENCES}

1. Bhugra D. Migration and mental health. Acta Psychiatr Scand 2004;109:243-58.

2. Iwasaki $\mathrm{M}$, et al. Cancer mortality among Japanese immigrants and their descendants in the state of Sao Paulo, Brazil, 1999-2001. Jpn J Clin Oncol 2004;34:673-80.

3. Kirmayer LJ, Narasiah L, Munoz M, et al. Common mental health problems in immigrants and refugees: general approach in primary care. CMAJ 2011;183:E959-67.

4. Spallek J, Zeeb H, Razum O. What do we have to know from migrants' past exposures to understand their health status? a life course approach. Emerg Themes Epidemiol 2011;8:6.

5. Norredam M, Nielsen SS, Krasnik A. Migrants' utilization of somatic healthcare services in Europe-- a systematic review. Eur J Public Health 2010;20:555-63.

6. Flood DM, Weiss NS, Cook LS, et al. Colorectal cancer incidence in Asian migrants to the United States and their descendants. Cancer Causes Control 2000;11:403-11.

7. Singh GK, Hiatt RA. Trends and disparities in socioeconomic and behavioural characteristics, life expectancy, and cause-specific mortality of native-born and foreign-born populations in the United States, 1979-2003. Int J Epidemiol 2006;35:903-19.

8. Syme SL, Marmot MG, Kagan A, et al. Epidemiologic studies of coronary heart disease and stroke in Japanese men living in Japan, Hawaii and California: introduction. Am J Epidemiol 1975;102:477-80.

9. Razum O, Wenner J. Social and health epidemiology of immigrants in Germany: past, present and future. Public Health Rev 2016;37:4.

10. Bundesamt für Migration und Flüchtlinge. Migrationsbericht des Bundesamtes für Migration und Flüchtlinge im Auftrag der Bundesregierung. 2016.

11. Eisfeld A. Vom Stolperstein zur Brücke - die Deutschen in Russland. In: Bergner C, Weber M, eds. Aussiedler- und Minderheitenpolitik in Deutschland Bilanz und Perpektiven. München: Oldenbourg Verlag, 2009:79-89.

12. Bundesverwaltungsamt. (Spät-)Aussiedler und ihre Angehörigen Zeitreihe 1950 - 2016. 2017.

13. Hensen J. Zur Geschichte der Aussiedler-und Spätaussiedleraufnahme. In: Bergner C, Weber M, eds. Aussiedlerund Minderheitenpolitik in Deutschland Bilanz und Perspektiven. München: Oldenbourg Verlag, 2009:47-61.

14. Haug S, Sauer L. Zuwanderung und Integration von (Spät-) Aussiedlern: Ermittlung und Bewertung der Auswirkungen des Wohnortzuweisungsgesetzes. Nürnberg: Bundesamt für Migration und Flüchtlinge, 2007.

15. Beauftragter für Aussiedlerfragen und nationale Minderheiten. Deutsche Minderheiten in Staaten der ehemaligen Sowjetunion 2013. 2013 https://www.aussiedlerbeauftragter.de/AUSB/DE/Themen/ 
deutsche-minderheiten/deutsche-minderheiten-gus/deutscheminderheiten-gus_node.html (Accessed 25 Apr 2018).

16. Bobak M, Marmot M. East-West mortality divide and its potential explanations: proposed research agenda. BMJ 1996;312:421-5.

17. Bobadilla JL, Costello CA. Premature death in the new independent states: overview. Washington D.C.: National Academy Press, 1997.

18. World Health Organization. Highlights on Health in the Russian Federation. 2006.

19. Worbs S, Bund E, Kohls M, et al. (Spät-) Aussiedler in Deutschland. Eine Analyse aktueller Daten und Forschungsergebnisse. Bundesamt für Migration und Flüchtlinge: Nürnberg, 2013.

20. Bund E, Kohls M, Worbs S. Zuwanderung und Integration von (Spät-) Aussiedlern in Deutschland. Zeitschrift für Ausländerrecht und Ausländerpolitik 2014;34:349-54.

21. Ronellenfitsch $\mathrm{U}$, Kyobutungi $\mathrm{C}$, Becher $\mathrm{H}$, et al. Large-scale, population-based epidemiological studies with record linkage can be done in Germany. Eur J Epidemiol 2004;19:1073-4.

22. Winkler V, Ott JJ, Holleczek B, et al. Cancer profile of migrants from the former Soviet Union in Germany: incidence and mortality. Cancer Causes Control 2009;20:1873-9.

23. Deckert A. Myocardial infarction incidence, cardiovascular disease, and external cause mortality pattern among German repatriates: the impact of factual circumstances [Phd Thesis]: University of Heidelberg, 2013.

24. Becher $\mathrm{H}$, Razum $\mathrm{O}$, Kyobutungi $\mathrm{C}$, et al. Mortalität von Aussiedlern aus der ehemaligen Sowjetunion. Dtsch Arztebl 2007;104:1655-61.

25. Winkler V, Holleczek B, Stegmaier C, et al. Cancer incidence in ethnic German migrants from the Former Soviet Union in comparison to the host population. Cancer Epidemiol 2014;38:22-7.

26. Kaucher S, Leier V, Deckert A, et al. Time trends of cause-specific mortality among resettlers in Germany, 1990 through 2009. Eur J Epidemiol 2017;32:289-98.

27. Deckert $A$, Winkler V, Meisinger $C$, et al. Myocardial infarction incidence and ischemic heart disease mortality: overall and trend results in repatriates, Germany. Eur J Public Health 2014;24:127-33.

28. Schmidtmann I, Sariyar M, Borg A, et al. Quality of record linkage in a highly automated cancer registry that relies on encrypted identity data.. GMS Med Inform Biom Epidemiol 2016;12.
29. Löwel H, Lewis M, Hörmann A, et al. Case finding, data quality aspects and comparability of myocardial infarction registers: results of a south German register study. J Clin Epidemiol 1991;44:249-60.

30. Kuhrs E, Winkler V, Becher H. Risk factors for cardiovascular and cerebrovascular diseases among ethnic Germans from the former Soviet Union: results of a nested case-control study. BMC Public Health 2012:12:190.

31. Volodina A, Bertsche T, Kostev K, et al. Drug utilization patterns and reported health status in ethnic German migrants (Aussiedler) in Germany: a cross-sectional study. BMC Public Health 2011;11:1.

32. Aparicio ML, Döring A, Mielck A, et al. Unterschiede zwischen Aussiedlern und der übrigen deutschen Bevölkerung bezüglich Gesundheit, Gesundheitsversorgung und Gesundheitsverhalten: eine vergleichende Analyse anhand des KORA-Surveys 2000. Soz Praventivmed 2005;50:107-18.

33. Jaehn P, Holleczek B, Becher $\mathrm{H}$, et al. Histologic types of gastric cancer among migrants from the former Soviet Union and the general population in Germany: what kind of prevention do we need? Eur J Gastroenterol Hepatol 2016;28:863-70.

34. Reiss K, Berger U, Winkler V, et al. Assessing the effect of regional deprivation on mortality avoiding compositional bias: a natural experiment. J Epidemiol Community Health 2013;67:213-8.

35. Deckert A, Winkler V, Meisinger C, et al. Suicide and external mortality pattern in a cohort of migrants from the former Soviet Union to Germany. J Psychiatr Res 2015;63:36-42.

36. Wichmann H-E, Kaaks R, Hoffmann W, et al. Die Nationale Kohorte. Bundesgesundheitsblatt Gesundheitsforschung Gesundheitsschutz 2012;55(6-7):781-9.

37. Winkler V, Leitzmann M, Obi N, et al. Response in individuals with and without foreign background and application to the National Cohort in Germany: which factors have an effect? Int $\mathrm{J}$ Public Health 2014;59:555-63.

38. World Health Organization. WHO mortality database 2015. http:// www.who.int/healthinfo/mortality_data/en/

39. Becher $\mathrm{H}$, Winkler V. Estimating the standardized incidence ratio (SIR) with incomplete follow-up data. BMC Med Res Methodol 2017;17:55 